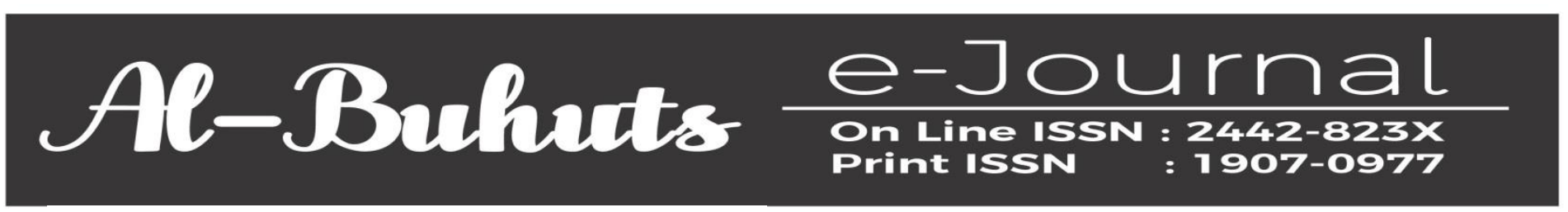

Volume 15 Nomor 2, Desember 2019

\title{
Analisis Perbedaan Kinerja Keuangan Bank Umum Milik Negara Konvensional dan Bank Umum Syariah di Indonesia
}

\author{
Sri Yunawati \\ Universitas Pasir Pengaraian \\ syuna.upp@gmail.com
}

\begin{abstract}
This study aims to to see what there are differences between the financial performance of BUMNN conventional and bank syariah, if reflected in the following the ratio of the CAR, non-performing loans to outstanding loans, $R O E, R O A, B O P O$, and LDR .In this research put it through statistical analysis of the ratio of descriptive financial used with describing the results of the highest value, the lowest score, the average, and the outcomes of the against a standard deviation, of a variable researched.In this research in conducting statistical testing data processing using kruskal walls, who was one of the probe in statistics non-parametrik who frequently used to test some samples who are not in charge. Based on tests carried out so the results showed that the financial performance of BUMN conventional and Bank Syariah seen from ratio car slightly went up , non-performing loans to outstanding loans, ROE, ROA, BOPO, and LDR there are significant differences.
\end{abstract}

Keywords: Bank Syariah, BUMN convetional, ROA, ROE, BOPO, LDR, NPL

\section{A. PENDAHULUAN}

Perbankan merupakan salah satu dari sistem keuangan yang berfungsi sebagai Financial Intermediary, yaitu lembaga yang mempunyai peran untuk mempertemukan antara pemilik dan pengguna dana. Oleh karena itu,kegiatan bank harus berjalan efiesien secara makro maupun mikro. Jasa perbankan pada umumnya sebagai penyedia mekanisme dan alat pembayaranyang efesien bagi nasabah. Untuk ini, bank menyediakan uang tunai, tabungan,dan kartu kredit Ini adalah peran bank yang paling penting dalamkehidupan ekonomi. Tanpa adanya penyediaan alat pembayaran yangefesien ini, maka barang hanya dapat diperdagangkan dengan cara barter yang memakan waktu.Bank yang menerima tabungan dari nasabah dan meminjamkannyakepada pihak yang membutuhkan dana, berarti bank meningkatkan arusdana untuk investasi dan pemanfaatan yang lebih produktif. Bila peran iniberjalan dengan baik, ekonomi suatu negara akan meningkat. Tanpa adanya 
saku seseorang, orang tidak dapat memperoleh pinjaman dan bisnis tidak dapat dibangun karena mereka tidak memiliki dana pinjaman.

Pada Praktiknya, Perbankan di Indonesia saat ini berdasarkan pada kegiatan oprasionalnya terdapat 2 jenis Perbankan, yaitu Bank Konvensional dan Bank Syariah (Ardiyana,2011)(Suhartono \& Yusra, 2019). Menurut Ulya(2014), Bank Konvensional yaitu dimana suatu perbankan Operasionalnya menerapkan metode Bunga, karena metode bunga sudah ada terlebih dahulu dipakai dibandingkan dengan metode bagi hasil. Sedangkan menurut Ningsih(2012), Bank Syariah yaitu suatu perbankan yang berdasarkan sesuai dengan prinsip syariah. yang artinya menghimpun dana dari masyarakat gunanya untuk di salurkan kembali ke pada masyarakat. Oleh Karena itu, dapat disimpulkan bahwa Bank Syariah yaitu Bank yang mengikuti sesuai syariah islam artinya berlandasan sesuai dengan alquran dan hadis.

\section{Kajian Pustaka}

Menurut Undang-Undang Nomor 10 Tahun 1998 tentang perbankan, yang dimaksud Bank adalah "Badan usaha yang menghimpun dana dari masyarakat dalam bentuk simpanan dan menyalurkannya kepada masyarakat dalam bentuk kredit dan bentuk-bentuk lainnya dalam rangka meningkatkan taraf hidup rakyat banyak"

Menurut ismail(2010) Bank merupakan lembaga keuangan yang fungsi utamanya adalah menghimpun dana dari masyarakat,menyalurkan dana kepada masyarakat, dan juga memberi pelayanan dalam bentuk jasa" perbankan.Dari fungsi tersebut,bank dapat mengembangkan dalam berbagai macam produk bank,yaitu produk bank yang terkait dengan penghimpun dana,penyaluran dana dan pelayanan jasa.

Menurut Herman Dermawi(2014) Bank adalah Lembaga keuangan yang kegiatan utamanya adalah menghimpun dana dari masyarakat dan menyalurkan nya kembali dana tersebut ke masyarakat serta memberikan jasa bank lainnya.sedang kan pengertian lembaga keuangan adalah setiap perusahaan yang bergerak dibidang keuangan dimana kegiatan nya baik hanya menghimpun dana,atau hanya menyalurkan dana atau keduanya menghimpun dan menyalurkan dana.

Menurut Kasmir(2017) Pengertian Bank adalah Perusahaan yang bergerak dalam bidang keuangan,artinya aktivitas perbankan selalu berkaitan dalam bidang keuangan sehingga berbicara bank tidak terlepas dari masalah keuangan. 


\section{Bank Konvensional}

Bank Konvensional adalah Bank yang menjalankan kegiatan usahanya secara konvensional dan berdasarkan jenisnya terdiri dari Bank Umum Dan Bank Perkreditan Rakyat( Booklet Perbankan Indonesia 2016 ). Sedangkan menurut Undang-undang 10 tahun 1998 Bank Konvensional adalah bank yang melaksanakan kegiatan usaha secara konvensional yang dam kegiatan nya memberikan jasa dalam lalu lintas pembayaran.

Bank konvensional pada umumnya menyerap dana masyarakat berupa tabungan, deposito, dan simpangan giro, dan setelah itu menyalurkan dana tersebut dalam bentuk kredit. (Ulya, 2014). Oleh Karena itu dapat disimpulkan bahwa Bank Konvensional adalah Bank yang pertama sekali beroperasi di Indonesia di bandingkan dengan Bank Syariah dan sudah memberikan nama yang baik pada masyarakat.

\section{Bank Syariah}

Bank Syariah adalah bank yang menjalankan kegiatan usahanya berdasarkan prinsip syariah dan menurut jenisnya terdiri dari atas Bank Umum Syariah, Unit Usaha Syariah dan Bank Pembiayaan Rakyat Syariah. Prinsip Syariah adalah prinsip hokum islam dalam kegiatan perbankan berdasarkan fatwa yang dikeluarkan oleh lembaga yang memiliki kewenangan dalam penetapan fatwa dibidang syariah( Booklet Perbankan Indonesia 2016). Perbankan syariah atau yang disebut dengan Perbankan Islam merupakan suatu sistem perbankan yang dikembangkan syariah dengan tata cara pengoperasiannya berdasarkan bermuamalah secara Islam, sesuai Al-Qur'an dan Al-Hadits Ulya (2014). Oleh Karena itu dapat disimpulkan bahwa Bank Syariah adalah Bank yang mengikuti semua ketentuan berdasarkan ajarah islam yang berpedoman pada syariah-syariah islam.

\section{Kinerja Keuangan Bank}

Menurut Kasmir(2017) Kinerja keuangan merupakan ukuran keberhasilan bagi direksi bank tersebut sehingga apabila kinerja ini buruk bukan tidak mungkin para direksi ini akan diganti,kinerja juga merupakan pedoman hal-hal apa saja yang perlu di perbaiki dan bagaimana cara memperbaikinya.

Dengan demikian dapat disimpulkan bahwa Kinerja Keuangan merupakan suatu perbankan yang dapat melakukan penilaian kinerja perusahaan sebagai pengambilan keputusan dengan melakukan analisis-analisis keuangan baik dan buruknya keadaan 
keuangan perbankan. Ada empat cara pengukuran kinerja keuangan sebuah bank yaitu:Capital, Asset Quality, Earning\&Efficiency, Liquidity (CAEL)

\section{Mengukur Kinerja Keuangan Bank Dengan Capital(Permodalan)}

Untuk mengukur capital atau modal sebuah bank digunakan beberapa rasio yaitu Total Capital,ATMR Resiko Kredit Operasional dan Pasar, Capital Adequency Ratio(CAR), Rasio Modal Terhadap Total Asset.Dari rasio tersebut biasanya mengetahui Capital sebuah bank biasanya dikatakan sehat apabila struktur modal yang kuat.Dalam penelitian ini peneliti menggunakan RasioCapital Adequacy Ratio (CAR) yang telah ditetapkan oleh Bank Indonesia.Capital Adequacy Ratio (CAR) merupakan rasio kecukupan modal yang menunjukkan kemampuan perbankan dalam menyediakan dana yang digunakan untuk mengatasi kemungkinan risiko kerugian. Rasio ini penting karena dengan menjaga CAR pada batas aman (minimal 8\%) berarti juga melindungi nasabah dan menjaga stabilitassistem keuangan secara keseluruhan.Semakin besar nilai CAR kemampuan perbankan semakin baik dalam menghadapi kemungkinan risiko kerugian.

\section{Mengukur Kinerja Keuangan Bank Dengan AssetQuality(Kualitas Aktiva Produktif)}

Untuk menilai Asset Quality atau kualitas aset sebuah bank digunakan rasio yaitu:Total Asset,Gross Loans, Rasio Non-Performing Loans terhadap Gross Loan, NonPerforming Loans Net,Rasio CKPN terhadap Asset produktif,Rasio Loan Loss Provissions terhadap Gross Loan.

Dalam penelitian ini peneliti menggunakan RasioAssets Quality (Kualitas Aktiva Produktif)yang diwakili oleh NPF (Non Performing Financing) atau NPL (NonPerforming Loans). Non Performing Loans (NPL) adalah tingkat pengembalian kredit yang diberikan deposan kepada bank dengan kata lain NPL merupakan kredit macetpada bank tersebut. Apabila semakin rendah NPL maka bank tersebut akan semakin mengalami keuntungan, sebaliknya bila NPL tinggi bank tersebut akan mengalami kerugian yang diakibatkan tingkat pengembalian kredit macet, penilaian didasarkan kepada kualitas aktiva yang dimiliki bank.

\section{Mengukur Kinerja Keuangan Bank Dengan Earning dan Effeciency(Pendapatan dan Efesiensi)}

Untuk menilai Earning\&Efficiency atau pendapatan\&efesiensi sebuah bank digunakan Rasio yaitu Total Profit,Return On Equity(ROE), Return On Asset(ROA),Net Interest 
Margin(NIM),BOPO,BiayaOperasional Non Bunga to Total Asset,BiayaOperasional Non Bunga To Pendapatan Bunga,Funding Cost,Fee Bassed Income To Total Income.

Dalam penelitian ini peneliti menggunakan RasioEarning \& Efficiency(Pendapatan \& Efesiensi). Analisis rasio rentabilitas bank adalah rasio yang digunakan untuk mengukur tingkat efisiensi usaha dan profitabilitas yang dicapai oleh bank yang bersangkutan (Kasmir,2013). Rentabilitas diukur dengan menggunakan tiga perhitungan yaitu Return OnEquity (ROE) adalah Laba bersih perdolar ekuitas modal. Return On Asset (ROA) adalah rasio yang mengukur kemampuan perbankan dalam menghasilkan profit atau laba (bisa disebut profitabilitas) dengan cara membandingkan laba bersih dengan sumber daya atau total asset yang dimiliki. Fungsinya adalah untuk melihat seberapa efektif perbankan dalam menggunakan asetnya dalam menghasilkan pendapatan.Semakin besar nilai ROA artinya semakin baik kemampuan perbankan dalam menghasilkan laba. Biaya Operasional terhadap Pendapatan Operasional (BOPO) adalah merupakan rasio yang menggambarkan efesiensi perbankan dalam melakukan kegiatan nya. Biaya operasionalnya adalah biaya bunga yang diberikan pada nasabah sedangkan pendapatan operasional adalah bunga yang didapat kan dari nasabah. Semakin kecil nilai BOPO artinya semakin efesien perbankan dalam beroperasi.

\section{Mengukur Kinerja Keuangan Bank Dengan Liquidity(Likuiditas)}

Untuk menilai Liquidity atau Likuiditas Bank digunakan Rasio Sebagai Berikut: Customer Deposit,Low cost Deposit,Loan Deposit Ratio(LDR),Rasio Aset Likuid Terhadap customer Deposit.Dalam penelitian ini peneliti menggunakan Rasio Liquidity (Likuiditas) Analisis likuiditas dalam penelitian ini dapat diukur dengan rasio Loan to Deposit Ratio (LDR) merupakan salah satu alat untuk mengukur kinerja keuangan sebuah bank dan digunakan untuk melihat kemampuan bank dalam menjadi liquiditasnya. Jika nilai LDR terlalu tinggi, artinya perbankan tidak memiliki likuiditas yang cukup memadai untuk menutup kewajibannya, sebalik nya jika nilai LDR terlalu rendah berarti perbankan memiliki liquiditas yang cukup memadai

\section{Perumusan Hipotesis}

Hipotesis merupakan jawaban sementara terhadap rumusan masalah penelitian. Berdasarkan kajian teori dan kerangka pemikiran di atas, maka dapat dikemukakan hipotesis sebagai berikut: 
$\mathrm{H}_{0}$ :Tidak terdapat perbedaan yang signifikan antara kinerja keuangan BUMN Konvensional dan Bank Umum Syariah.

$\mathrm{H}_{1}$ : Terdapat perbedaan yang signifikan antara kinerja keuangan BUMN Konvensional dan Bank Umum Syariahjika dilihat dari masing-masing Rasio.

\section{B. METODE PENELITIAN}

Populasi yang digunakan dalam penelitian ini yakni seluruh BUMN Konvensional dan Bank Umum Syariah yang terdaftar di Bursa Efek Indonesia. Teknik sampling dalam penelitian ini adalah Non-probability Sampling dengan metode Purposive Sampling yaitu teknik pengambilan sampel dari populasi berdasarkan suatu kriteria-kriteria tertentu diantaranya:

1. BUMN yang juga memiliki Bank Umum Syariah

2. Bank yang mempublikasikan laporan keuangan pada periode $2015-2017$

Berdasarkan kriteria tersebut di atas, maka diperolah sampel sebanyak enam bank umum yang terdiri dari tiga BUMN Konvensional dan tiga Bank Umum Syariah yakni PT Bank Negara Indonesia Tbk, PT Bank Rakyat Indonesia Tbk, PT Bank Mandiri Tbk, PT Bank Syariah BNI, PT Bank Syariah BRI, dan PT Bank Syariah Mandiri.

Sesuai dengan kriteria yng telah ditetapkan makam terdapat tiga BUMN konvensional dan tiga Bank Umum Syariah, yang akan diteliti.

\section{Variabel Penelitian dan Definisi Operasional Variabel}

Dalam penelitian ini terdapat enam variabel yakni Rasio Capital Adequacy Ratio (CAR), Non Performing Loan (NPL), Return on Assets (ROA), ReturnonEquity (ROE), BOPO, dan LoantoDepositRatio (LDR).

\section{Capital (Permodalan)}

Aspek permodalan ini yang dinilai adalah permodalan yang didasarkan kepada kewajiban penyediaan modal minimum bank Penilaian ini didasarkan pada Capital Adequacy Ratio (CAR) yang telah ditetapkan oleh Bank Indonesia.Capital Adequacy Ratio (CAR) adalah rasio yang memperlihatkan seberapa jauh seluruh aktiva bank yang mengandung aktiva risiko (kredit, penyertaan, surat berharga, tagihan pada bank lain) ikut dibiayai dari dana modal sendiri bank disamping memperoleh dana-dana dari sumber diluar bank, seperti dana masyarakat, pinjaman (utang), dan lain lain. Semakin tinggi CAR 
maka semakin besar pula sumber daya finansial yang dapat digunakan untuk keperluan pengembangan usaha dan mengatisipasi potensi kerugian yang diakibatkan oleh penyaluran kredit (Wardiantika\& Rohmawati, 2014).

\section{AssetsQuality (Kualitas Aktiva Produktif)}

Kualitas Aset (Asset Quality) yaitu untuk menilai jenis-jenis aset yang dimiliki oleh bank.Penilaian aset harus sesuai dengan Peraturan oleh Bank Indonesia dengan memperbandingkan antara aktiva produktif yang diklasifikasikan dengan aktiva produktif.Kemudian rasio penyisihan penghapusan aktiva produktif terhadap aktiva produktif diklasifikasikan. (Yanti \& Susila. 2014)

Kasmir (2012) mengatakan dalam aspek ini upaya yang dilakukan adalah untuk menilai jenis-jenis aset yang dimiliki oleh bank.Penilaian aset harus sesuai dengan Peraturan oleh Bank Indonesia dengan membandingkan antara aktiva produktif yang diklasifikasikan terhadap aktiva produktif.Kemudian rasio penyisihan penghapusan aktiva produktif terhadap aktiva produktif di klasifikasikan.

\section{Earning dan Efficiency (Pendapatan dan efesiensi)}

Analisis rasio rentabilitas bank adalah rasio yang digunakan untuk mengukur tingkat efisiensi usaha dan profitabilitas yang dicapai oleh bank yang bersangkutan (Kasmir, 2013). Rasio rentabilitas yang digunakan adalah ROA,ROE dan BOPO. Rasio ini digunakan untuk mengukur kemampuan manajemen bank dalam memperoleh keuntungan (laba) secara keseluruhan.Semakin besar ROA suatu bank, maka semakin besar pula tingkatkeuntungan yang dicapai bank tersebut dan semakin baik pula posisi bank tersebut dari segi penggunaan aset .

\section{Liquidity (Likuiditas)}

Perhitungan likuiditas bank digunakan untuk mengukur kemampuan bank dalam memenuhi kewajiban jangka pendeknya pada saat ditagih (Kasmir, 2013). Analisis likuiditas dalam penelitian ini dapat diukur dengan rasio Loan to Deposit Ratio (LDR) untuk bank konvensional atau Finance to Deposit Ratio (FDR) untuk bank syariah. Rasio tersebut menyatakan seberapa jauh kemampuan bank dalam membayar kembali penarikan dana yang dilakukan deposan dengan mengandalkan pembiayaan sebagai sumber likuiditasnya. Dengan kata lain, seberapa jauh pemberian pembiayaan terhadap nasabah 
dapat mengimbangi kewajiban bank untuk segera memenuhi permintaan. Semakin tinggi rasio ini memberikan indikasi renadahnya kemampuan likuiditas bank yang bersangkutan.

\section{Teknik Analisis Data}

Dalam penelitian ini menggunakan Analisis statistik deskriptif terhadap rasio keuangan yang digunakan dengan menjelaskan hasil dari nilai tertinggi, nilai terendah, rata-rata, dan hasil terhadap standar deviasi, dari variabel yang diteliti. Pada penelitian ini dalam melakukan Pengolahan data menggunakan Uji Kruskal Walls, tujuannya adalah bagaimana membandingkan kinerja keuangan BUMN Konvensional dengan Bank Umum Syariah dengan menggunakan uji statistik Kruskal Walls, yang merupakan salah satu alat uji dalam statistik non-parametrik yang sering digunakan untuk menguji beberapa sampel yang tidak berhubungan (Sujarweni, 2016)

\section{HASIL DAN PEMBAHASAN}

Dalam Penelitian ini akan melihat perbandingan dari Bank Syariah danBank Konvensional yang akan dilihat dari kinerja keuangan dari setiap bank syariah dan bank konvensional yang dianalisis dengan mengukur Rasio CAR, NPL, ROA, ROE, BOPO dan LDR. Berdasarkan perhitungan yang dilakukan dengan bantuan program SPSS, diperoleh hasil sebagai berikut:

Tabel 1

Test Statistics ${ }^{\text {a,b }}$

\begin{tabular}{|l|r|r|r|l|r|r|}
\hline & CAR & NPL & ROE & ROA & BOPO & \multicolumn{1}{l|}{ LDR } \\
\hline Chi-square & 13,304 & 15,175 & 13,997 & 14,602 & 14,325 & 11,462 \\
df & 5 & 5 & 5 & 5 & 5 & 5 \\
Asymp. &, 021 &, 010 &, 016 &, 012 &, 014 &, 043 \\
Sig. & & & & & & \\
\hline
\end{tabular}

a. Kruskal Wallis Test

b. Grouping Variable: BANK 
Analisis Perbedaan Kinerja Kenangan Bank umum Milike Negara Konvensional dan Bank Umum Syariah di indonesía

Dalam penelitian ini, menggunakan uji Kruskal Walls dengan membandingkan hasil perhitungan chi-square dan tabel chi-square. Nilai dari chi-square tabel adalah sebesar 11,07. Dari perhitungan di atas diperoleh CAR sebesar 13,304; NPL sebesar 15, 175; ROE sebesar 13,997; ROA sebesar 14,602; BOPO sebesar 14,325; dan LDR sebesar 11,462. Jika dibandingkan dengan chi-square tabel maka nilai terbebut seleruhnya adalah lebih besar dari 11,07 dan jika dilihat dari tingkat signifikansi seluruhnya kurang dari 5\%. Maka hasil penelitian in diperoleh bahwa, terdapat perbedaan yang signifikan mengenai kinerja keuangan BUMN Konvensional dan Bank Umum Syariah.

\section{Penutup}

Berdasarkan hasil pembahasan tersebut maka dapat disimpulkan bahwa kinerja keuangan BUMN Konvensional dan Bank Umum Syariah dilihat dari rasio CAR, NPL, ROE, ROA, BOPO, dan LDR terdapat perbedaan yang signifikan.

Dari Hasil Kesimpulan dalam penelitian ini, penulis memberikan saran periode pengamatan pada penelitian ini hanya lima tahun yaitu tahun 2012-2016. Untuk Penelitian yang akan datang sebaiknya menambah jumlah periode pengamatan untuk mendapatkan hasil yang lebih korprehensif. Bagi Penelitian yang akan datang, sebaiknya menambah rasio keuangan lain. Misalnya, menggunakan NPM. Bagi Peneliti yang akan datang, sebaiknya memperluas objek penelitian lain, tidak hanya pada perusahaan perbankan saja,

tetapi juga pada perusahaan atau industri lain, sehingga hasil penelitian dapat digeneralisasi.

\section{DAFTAR PUSTAKA}

Darmawi Herman. 2014. Manajemen Perbankan.PT Bumi aksara:Jakarta

Dwi Vina Demetrin, 2017. Analisis Perbedaan Kinerja Keuangan Bank Umum Syariah dengan Bank Konvensional di Indonesia (Sebuah Studi Komparatif), Sekolah Tinggi Ilmu Ekonomi KBP Padang

Ismail.2010.Akuntansi Bank.Kencana Prenada Media Group:Rawamungun-Jakarta.

Kasmir.2017.Bank dan Lembaga Keuangan Lainnya.PT Raja Grafindo Persada:Jakarta.

Kasmir.2012. Manajemen Perbankan.PT Raja Grafindo Persada:Jakarta.

Sujarweni, V. Wiratna, 2016. Penelitian Akuntansi dengan SPSS 
Ulya (2014). Earnings dan Capital. Program Studi Keuangan Islam Fakultas Syari 'ah dan Hukum Universitas Islam Negeri Sunan Kalijaga.

Zaharman, 2016. Analisis Perbedaan Kinerja Keuangan Perbankan Syariah dengan Perbankan Konvensional di Indonesia. Jurnal Ilmiah Ekonomi dan Bisnis, Vol. 14, No. 2 